\author{
Katarzyna Kuchowicz \\ Uniwersytet Jagielloński \\ k.kuchowicz@gmail.com
}

\title{
Recht auf Heimat. Literackie echa górnośląskiej turystyki ojczyźnianej
}

\section{Recht auf Heimat. Literary Echoes of the Upper-Silesian Homeland Tourism}

\begin{abstract}
The notion of Recht auf Heimat (right to homeland), popular in the 1950, was one of the most important postulates of Charta der deutschen Heimatvertriebenen (Charter of the German Expellees). The assumptions of this document have never been fully implemented; first and foremost, the return of the expellees to their native lands has been impossible. Since the re-settlement in the abandoned territories was, for various reasons, out of the question, an attractive, and often the only possible, form of encountering one's home country, were excursions, which Anna Borne and Andrzej Doliński referred to as "homeland tourism."

Adopting criteria of a small-scope theory, the article analyzes literary echoes of the Upper-Silesian homeland tourism on the example of memoirs whose authors originated from Gleiwitz: Horst Bienek, Wolfgang Bittner and Wolfgang Bukowski. The Recht auf Heimat postulate and the poetics of Vertreibungsliteratur provide the context for the considerations. The main objective of the article is to answer the question in what way homeland tourism exerted influence on forcibly repatriated writers and how it shaped the image of the visited places.
\end{abstract}

Keywords: Horst Bienek, Wolfgang Bittner, Wolfgang Bukowski, Upper Silesia, little homeland, forced displacement, World War II

Streszczenie: Popularne w latach pięćdziesiątych ubiegłego wieku pojęcie Recht auf Heimat (prawo do ojczyzny) było jednym z najważniejszych postulatów ogłoszonej w 1950 roku Charta der deutschen Heimatvertriebenen (tak zwanej Karty wypędzonych). Założenia dokumentu nigdy nie zostały w pełni zrealizowane, przede wszystkim niemożliwy był powrót przymusowych emigrantów do rodzinnych stron. Ponowne zasiedlenie opuszczonych terytoriów z wielu względów było wykluczone, dlatego atrakcyjną, i często jedyną możliwą, formą spotkania z ojczyzną stały się wycieczki, które Hanna Borne i Andrzej Doliński określili mianem turystyki ojczyźnianej.

Kierując się kryteriami teorii małego zasięgu, w artykule dokonano analizy literackiego echa górnośląskiej turystyki ojczyźnianej na przykładzie utworów wspomnieniowych, których autorzy pochodzili z Gliwic: Horsta Bienka, Wolfganga Bittnera oraz Wolfganga 
Bukowskiego. Za kontekst rozważań służy postulat Recht auf Heimat oraz poetyka Vertreibungsliteratur. Głównym celem artykułu jest próba odpowiedzi na pytanie, jak turystyka ojczyźniana wpływa na twórczość przymusowo przesiedlanych pisarzy oraz w jaki sposób kształtuje obraz odwiedzanych miejsc.

Słowa kluczowe: Horst Bienek, Wolfgang Bittner, Wolfgang Bukowski, Górny Śląsk, mała ojczyzna, przymusowe migracje, II wojna światowa

Wir haben unsere Heimat verloren. Heimatlose sind Fremdlinge auf dieser Erde. Gott hat die Menschen in ihre Heimat hineingestellt. Den Menschen mit Zwang von seiner Heimat trennen, bedeutet, ihn im Geiste töten.

Charta der deutschen Heimatvertriebenen

Relacja człowieka z przestrzenią jest jednym z podstawowych doświadczeń egzystencjalnych, które definiują tożsamość ${ }^{1}$. Konstytuujący się podmiot określa siebie za pomocą kategorii spacjalnych, korzystając z różnych wzorców, zarówno lokalnych, jak i ponadnarodowych. Przestrzeń, niezależnie od wyznaczonych jej granic, zdaniem badaczy ufundowana jest na jednostkowym doświadczeniu cielesności bądź rozumienia ${ }^{2}$, a w procesie indywidualnej konceptualizacji zostaje napełniona sensem oraz znaczeniem, stając się miejscem ${ }^{3}$. Jednym z nich, najważniejszym dla człowieka, jest dom. Zuzanna Dziuban zauważa, że w pojęciu zamieszkiwania mieści się bliskość, swojskość i przynależność, odsyłające „do intymnego doświadczenia miejsca-domu” ${ }^{4}$, którego opuszczenie daje się rozpatrywać w dwóch aspektach, po pierwsze, jako inicjacja i wejście w dorosłe życie, po drugie, jako wydarzenie traumatyczne. W obu wypadkach podmiot jest zmuszony do konfrontacji ze światem, staje wobec zderzania lokalnego i światowego, znanego i nieznanego, dlatego też opuszczenie domu często jest najważniejszym punktem biografii.

Świadectwa przymusowych migracji, które latach 1944-1948 dotknęły milionów ludzi, obrazują z jednej strony tradycyjne zadomowienie i związek autora z rodzinnym miejscem, z drugiej - traumę, jaką niesie ze sobą konieczność opuszczenia ojczyzny. Decyzje o wyjeździe podejmowane były z różnych względów, zarówno ekonomicznych, jak i bezpieczeństwa. Za przymusowymi migracjami kryły się także regulacje prawne, na mocy których wysiedlano

${ }^{1}$ M. Mikołajczak, Geografia wyobrażona regionu - wstęp do regionalnej komparatystyki [w:] Geografia wyobrażona regionu. Literackie figury przestrzeni, red. D. Kalinowski, M. Mikołajczak, A. Kuik-Kalinowska, Kraków 2014, s. 6.

2 Z. Dziuban, Doświadczenie [w:] Kulturowe studia miejskie. Wprowadzenie, red. E. Rewers, Warszawa 2014, s. 171.

3 Y.-F. Tuan, Przestrzeń i miejsce, tłum. A. Morawińska, Warszawa 1987, s. 75, 99, 173.

${ }^{4}$ Z. Dziuban, dz. cyt., s. 171. 
całe grupy etniczne. Zjawisko nie miało jednorodnego przebiegu, część ludności musiała spakować dobytek w godzinę, ograniczając się do kilku kilogramów bagażu i ręcznego wózka, inni mieli do dyspozycji wóz i prawo do zabrania żywego inwentarza. Niezależnie od okoliczności towarzyszących migrujący ruszając w nieznane, opuszczali rodzinne strony, zostawiając za sobą miejsca dobrze znajome i oswojone. Pożegnanie oraz rezygnacja z poczucia bezpieczeństwa, którego choć w minimalnym stopniu dostarczał w czasie wojny dom, przychodziły przymusowo przesiedlanym z dużą trudnością, Bolesław Rowiński pokreślił we wspomnieniach silne emocje z tym związane:

Pożegnanie z domem jest tragiczne. Ojciec żegna się z każdym pomieszczeniem, z każdym kątem domu, podwórka, ogrodu. Obchodzi, przystaje na chwilę, jakby przypominał sobie spędzone tu lata i pracę, jaką włożył w to wszystko, co było jego własnością, a teraz musi to opuścić. Matka płacze, nie jest zdolna do żadnego gestu pożegnania. Nastrój smutku udziela się mnie i siostrze. Ten dom, podwórko i ogród były cząstką naszego życia. Dziś wyjeżdżamy w nieznane 5 .

Zniszczenie intymnego związku z domem, najbliższą okolicą oraz odebranie prawa do samodzielnego wyboru miejsca egzystencji zasadniczo wpływa na kondycję podmiotu, zmusza do redefiniowana tożsamości oraz szukania nowej formuły opisu ,ja”. Nakładające się na doświadczenie przymusowych migracji poczucie niesprawiedliwości i krzywdy sprawiły, że porzucenie tożsamości wypracowanej w ramach lokalnych wzorców wraz ze zmianą kategorii spacjalnych, na podstawie których podmiot dokonywał samookreślenia, stało się dla wysiedlanych niezwykle trudne lub wręcz niemożliwe do zaakceptowania. Część przesiedlonych nie poradziła sobie z procesem asymilacji, we wspomnieniach pojawiają się przypadki depresji, a nawet nagłe pogorszenie stanu zdrowia i niespodziewana śmierć ${ }^{6}$.

Dla większości przymusowych migrantów małe ojczyzny na zawsze pozostały prawdziwymi i jedynymi ojczyznami, wspominanymi z sentymentem i tęsknotą, a postawę wielu z nich można interpretować w kontekście mitu wygnańca, w który „wpisana jest niejako idea wiecznego powrotu ku temu, co zostało porzucone, odzyskania tego, co zabrane (...)" powrotu i posiadania ojczyzny, rozumianej jako ziemia ojców i kraina dzieciństwa, została napisana Charta der deutschen Heimatvertriebenen (tak zwana Karta wypędzonych). Dokument został podpisany 5 sierpnia 1950 roku w Stuttgarcie z inicjatywy wypędzonych Niemców zrzeszonych w Vereinigung

${ }^{5}$ B. Rowieński, Z Huculszczyzny na Dolny Ślask [w:] Wypędzeni ze Wschodu, red. H.-J. Bömelburg, R. Stößinger, R. Traba, tłum. J. Górny i in., Olsztyn 2001, s. 147-148.

6 Zob. tamże, s. 157.

7 J. Święch, Wygnanie. Prolegomena do tematu [w:] Narracja i tożsamość. Antropologiczne problemy literatury, t. 2, red. W. Bolecki, R. Nycz, Warszawa 2004, s. 112. 
der Landsmannschaften (Zjednoczone ziomkostwa). 27 października 1957 roku Vereinigung der Landsmannschaften połączyło się z Bund vertriebener Deutscher (Związek Wypędzonych Niemców), tworząc współczesny BvD. Charta der deutschen Heimatvertriebenen stanowi najważniejszy dokument, a Recht auf Heimat (prawo do ojczyzny) należy uznać za główny postulat organizacji. W Karcie zostało wprost wyrażone żądanie respektowania danego od Boga prawa do ojczyzny (w oryginale: „Wir haben dieses Schicksal erlitten und erlebt. Daher fühlen wir uns berufen zu verlangen, daß das Recht auf die Heimat als eines der von Gott geschenkten Grundrechte der Menschheit anerkannt und verwirklicht wird" $\left.{ }^{3}\right)$, które zrozumiałe jest w kontekście kategorii spacjalnych organizujących tożsamość, ale nie jako boskie nadanie. Problematyczne nie jest darzenie utraconej ojczyzny ciepłymi uczuciami, ale zupełny brak gotowości do zadomowienia się w nowym miejscu, która powinna cechować wygnańca. Utwierdzanie się w przekonaniu, że powrót będzie możliwy wraz z polityczną walką o uznanie postulatów ziomkostw, mogło utrudnić wielu przesiedlonym oswajanie się z nową przestrzenią egzystencjalną, jawiącą się jako tymczasowa. Zamknięcie się we własnej przeszłości uniemożliwia odbudowanie rodzinnego domu wraz z całym jego emocjonalnym uposażeniem, gdy tymczasem, jak twierdzi Jerzy Święch, wygnanie powinno się zakończyć pozornym odcięciem od przeszłości, gdyż tylko dzięki temu możliwe jest tworzenie przestrzeni wyobrażonych oraz rozbudowanie wspomnień wraz z wypełnianiem luk pamięci, co pozwala wejść w trzecią fazę - pojednania się ze światem". Charta der deutschen Heimatvertriebenen oświetla jednak tylko moment utraty, eksponując konieczność powrotu, oraz zachęca nie do budowania nowych struktur tożsamościowych i przepracowania traumy przymusowych migracji, ale do nieustannego jej przeżywania przez podkreślanie doznanej krzywdy, wykluczając tym samym pełną asymilację.

Dokument z 1950 roku zasługuje także na krytykę ze względu na próbę zawłaszczenia przymusowych migracji wyłącznie przez niemieckich wypędzonych, którzy po drugiej wojnie światowej musieli opuścić dotąd zamieszkiwane terytoria ${ }^{10}$. W Karcie zaakcentowano „das Schicksal der deutschen Heimatvertriebenen” („los niemieckich wypędzonych”), których, w ujęciu autorów dokumentu, spotkało największe cierpienie. Abstrahując od dyskusji na temat najboleśniejszych doświadczeń wojennych oraz wyznaczania grupy najbardziej poszkodowanych, warto zwrócić uwagę, że Recht auf Heimat zasadniczo nie było udzielane ani Polakom, ani Ukraińcom, ani Łemkom czy Estończykom bądź jakiejkolwiek innej grupie etnicznej, która była objęta przymusowymi

${ }^{8}$ Pełny tekst Charta der deutschen Heimatvertriebenen dostępny jest w językach niemieckim, angielskim, polskim, rosyjskim, czeskim, rumuńskim na stronie BvD, http://www.bund-der-vertriebenen.de/charta-der-deutschen-heimatvertriebenen.html, dostęp: 28.04.2016.

9 Zob. J. Święch, dz. cyt., s. 115.

10 Zob. B. Halicka, Polski Dziki Zachód. Przymusowe migracje i kulturowe oswajanie Nadodrza 1945-1948, tłum. A. Łuczak, Kraków 2015, s. 26-33. 
migracjami w latach 1944-1948. Co więcej, prawo do ojczyzny przyznano także Niemcom, którzy emigrowali w ramach akcji Heim ins Reich, zasiedlając terytoria podbite przez III Rzeszą i pełniąc niejako funkcję kolonizatorów tych obszarów.

Jednostronność dokumentu, działań BvD oraz agresywna polityka historyczna, której symbolem może być Erika Steinbach, miały duży wpływ na stosunki polsko-niemieckie. Robert Traba oraz Robert Żurek, rozważając sensowność polityki wobec historii i zaangażowanie w kontekście przymusowych migracji, oceniają, że

Charakterystyczną cechą polsko-niemieckiego dialogu o wysiedleniach była i jest jego nierównoczesność i nierównowaga potencjałów tożsamościowych, odmiennych znaczeń w wewnętrznych sporach o historię ${ }^{11}$.

Każda ze stron dyskusji o przymusowych migracjach, opisując zjawisko, inaczej rozkłada akcenty, porozumienie utrudniają również niezwykle silne resentymenty oraz przeświadczenie niemieckich wypędzonych o wyjątkowej brutalności wysiedleń, niesprawiedliwości i krzywdzie doznanej ze strony Polaków. Zjawisko w prostej linii prowadziło do nawarstwiania się trudności związanych z akceptacją nowej rzeczywistości. Polityczny aspekt kontrowersji wokół Flucht und Vertreibung to nie tylko próba przeforsowania modelu historii zgodnego z interesem konkretnej grupy, ale także instrumentalizacja pojęcia (niemieckiej) ofiary, której konsekwencją był, a poniekąd jest nadal, rodzaj litości nad przymusowo wysiedlonymi. Warto zaznaczyć, że pojęcie Recht auf Heimat, mimo upływu ponad pięćdziesięciu lat od jego sformułowania, wciąż nie straciło na znaczeniu i komplikuje przepracowanie powojennej utraty ojczyzny.

Postulatu dotyczącego konieczności stworzenia przymusowym migrantom możliwości ponownego zasiedlenia terytoriów, które musieli opuścić, z wielu względów nie można było zrealizować. Pewną namiastką pozwalającą choć częściowo „odzyskać” utraconą ojczyznę, a przynajmniej odbudować związek z rodzinnymi stronami, niezbędny do podtrzymania ustalonych przed przymusową migracją wzorców tożsamości, jest turystyka sentymentalna, zwana też etniczną i ojczyźnianą. Hanna Borne oraz Andrzej Doliński definiują ten rodzaj mobilności jako „podróże zagraniczne odbywane do kraju pochodzenia przodków, do ziemi ojców, a także spotkania z grupami etnicznymi w odwiedzanym kraju" ${ }^{12}$. Wzrost atrakcyjności obszarów pogranicznych stał się zauważalny na przełomie lat osiemdziesiątych i dziewięćdziesiątych ubiegłego wieku,

${ }^{11}$ R. Traba, R. Żurek, Vertreibung czy „przymusowe wysiedlenia”? Polsko-niemiecki spór o pojęcia, pamięć i sens uprawiania polityki wobec historii [w:] Przetom $i$ wyzwanie. XX lat polsko-niemieckiego Traktatu o dobrym sąiedztwie i przyjaznej wspótpracy 1991-2011, red. W.M. Góralski, Warszawa 2011, s. 420.

12 H. Borne, A. Doliński, Organizacja turystyki, Warszawa 1998, s. 34. 
w tym czasie "granice polityczne zmieniały swoją rolę i stały się bardziej otwarte a większość barier uległa osłabieniu" ${ }^{13}$. Na skutek przemian geopolitycznych turystyka sentymentalna stawała się coraz prostsza, a sama potrzeba odwiedzin była tak duża, że przymusowo wysiedlani korzystali z niej przy każdej okazji, niezależnie od położenia geograficznego małej ojczyzny ${ }^{14}$. Doświadczenie wychodźstwa zmienia jednak perspektywę oglądu rodzinnych stron, nie chodzi tylko o wykorzystanie mitu arkadyjskiego w opisie ojczyzny, ale także o mentalną próbę rekonstrukcji relacji z przestrzenią i konfrontację wspomnień z rzeczywistością. Można powiedzieć, posługując się formułą Horsta Bienka, że turystyka sentymentalna to próba odnalezienie „skarbu Heimat" ${ }^{15}$.

Podróż do ojczyzny jest ważnym elementem przepracowywania traumy przesiedlenia oraz niezwykle silnym bodźcem artystycznym. Znaczna część pisarstwa Horsta Bienka, Wolfganga Bittnera oraz Wolfganga Bukowskiego wynika bezpośrednio z doświadczenia przymusowej migracji oraz uprawianej przez literatów turystyki ojczyźnianej. Twórczość wymienionych pisarzy można z powodzeniem interpretować na podstawie postulatu Recht auf Heimat oraz poetyki Vertreibungsliteratur. Znajomość kontekstu politycznego pozwala uchwycić klisze charakterystyczne dla wypracowanego w ramach Związku Wypędzonych aparatu pojęciowego, którym posługiwał się Bittner. Pisarz sam siebie określa mianem wypędzonego ${ }^{16}$, przymusowe migracje traktuje jako wyłącznie niemieckie (GZKG, s. 125) i powiela opisane przez Haralda Welzera mechanizmy wypierania rodzinnych związków $\mathrm{z}$ nazistami ${ }^{17}$. Aby umieścić twórczość Bienka w powiązanym z polityką BdV nurcie „Flucht und Vertreibung”, należy spojrzeć całościowo na pisarstwo gliwiczanina, nie jest to jednak pomysł nowy. Próby odczytania prozy autora Pierwszej polki w kontekście wypędzeń należą chyba do najczęstszych w literaturze przedmiotu, warto wymienić choćby prace Louisa F. Helbiga z lat dziewięćdziesiątych ${ }^{18}$. Należy zwrócić także uwagę na koncepcję „niemieckiego Wschodu”, z którą z jednej

${ }^{13}$ M. Więckowski, Turystyka na obszarach przygranicznych Polski, Warszawa 2010, s. 93-94.

${ }_{14}$ Za przykład niech posłuży zachowanie Alicji Michałowskiej, która wspomina powrót do litewskich Kołtynian, zob. A. Michałowska, Gdzie Żejmiana, gdzie Odra [w:] Wypędzeni ze Wschodu, dz. cyt., s. 128-137.

${ }^{15}$ H. Bienek, Podróż w krainę dzieciństwa. Spotkanie ze Śląskiem (wydanie dwujęzyczne), tłum. M. Podlasek-Ziegler, Gliwice 1993, s. 342. Wszystkie cytaty podawane będą za tym wydaniem i lokalizowane w tekście głównym ze skrótem PWKD oraz numerem strony.

${ }_{16}$ W. Bittner, Gleiwitz heißt heute Gliwice: eine deutsche-polnische Gesichte. Gliwice zwano kiedyś Gleiwitz: historia niemiecko-polska, Oberhausen, Wrocław 2003, s. 133. Wszystkie cytaty podawane będą za tym wydaniem i lokalizowane w tekście głównym ze skrótem GZKG.

${ }_{17}$ H. Welzer, S. Moller, K. Tschuggnall, „Dziadek nie byt nazistą”. Narodowy socjalizm i Holokaust w pamięci rodzinnej, tłum. P. Masłowski [w:] Pamięć zbiorowa i kulturowa. Wspótczesna perspektywa niemiecka, red. M. Saryusz-Wolska, Kraków 2009, s. 351-410.

${ }_{18}$ L.F. Helbig, Der ungeheure Verlust: Flucht und Vertreibung in der deutschsprachigen Belletristik der Nachkriegszeit. 3., um den aktuellen Forschungsstand und eine Register ergänzte Auflage, Wiesbaden 1996. 
strony Bienek wchodzi w polemikę, próbując ukazać Śląsk wielokulturowy, $\mathrm{z}$ drugiej ją popiera, przyznając w Podróży $w$ kraine dzieciństwa, że była to ziemia wyłącznie niemiecka (PWKD, s. 221). Prawdą jest, że twórczość Bukowskiego, Bittnera i Bienka jako taka nie ma charakteru politycznego, pełni też inne funkcje, ale jednocześnie została ufundowała na doświadczeniu przymusowych migracji i powstała w atmosferze politycznej ekspozycji zjawiska wypędzeń, za którą odpowiedzialny był BdV. Marginalizowany w badaniach nad literaturą przymusowych migracji kontekst Recht auf Heimat może wiele wyjaśnić, szczególnie w refleksji nad chętnie podejmowanymi przez przesiedlanych podróżami w rodzinne strony. Prawo do ojczyzny oraz mająca duży oddźwięk społeczny polityka ziomkostw z pewnością wpłynęły także na sposoby autoidentyfikacji oraz poczucie tożsamości, $\mathrm{BdV}$ stwarzało przestrzeń budowania wspólnoty wykluczonych i pomagało w pielęgnowaniu mitycznych obrazów utraconych ojczyzn, które - jak wiemy dzięki relacjom z podróży sentymentalnych - powodowały zawód i rozczarowanie powojenną rzeczywistością.

Zarówno Horst Bienek, jak i Wolfgang Bukowski oraz Wolfgang Bittner urodzili się w Gleiwitz (dziś Gliwice na Górnym Śląsku), dwóch pierwszych twórców było rówieśnikami (przyszli na świat kolejno w 1930 i 1932 roku), natomiast najmłodszy z nich, Bittner, został powity w 1941 roku. Wszyscy opuścili miasto w tym samym okresie, na przełomie 1945 i $1946 \mathrm{roku}^{19}$. Zbieżności biograficznych można wymienić więcej, szczególnie między Bienkiem a Bukowskim, którzy, będąc równolatkami, dzielili doświadczenia pokoleniowe, takie jak zaangażowanie w struktury Hitlerjugend. Najistotniejsze jednak, że odnosili się do tej samej przestrzeni miejskiej, a Gleiwitz było dla nich domem, który przez lata funkcjonował w ich wspomnieniach jako punkt odniesienia dla poczucia tożsamości, dzięki czemu możliwe było podtrzymanie lokalnego doświadczenia miejsca.

Podróż w rodzinne strony miała przede wszystkim charakter sentymentalny, pisarze przypisywali Gliwicom szczególne znaczenie, łączyła ich z miastem emocjonalna więź, którą najmocniej zaakcentował Bienek. Dla niego Śląsk miał charakter sacrum: „Właściwie chciałabym, jak papież, uklęknąć i ucałować ziemię, śląską ziemią" (PWKD, s. 191). Egzaltacja, którą można dostrzec w zachowaniu Bienka, nie jest widoczna w tekstach Bukowskiego i Bittnera,

19 Zob. W. Bukowski, Als wir jung in Gleiwitz waren..., Dülmen 2014, s. 133-142.Wszystkie cytaty podawane będą za tym wydaniem i lokalizowane w tekście głównym ze skrótem AWJ oraz numerem strony. W. Bittner, GZKG (s. 30, 120). W przypadku Horsta Bienka trudno jednoznacznie stwierdzić, kiedy opuścił Gliwice, pisarz podawał dwie daty: 1945 oraz 1946 rok. Por. H. Bienek, Brzozy i wielkie piece. Dzieciństwo na Górnym Ślasku, tłum. W. Szewczyk, Gliwice 1991, s. 80 oraz tenże, Stopniowe zamieranie krzyku, tekst prozą tłum. M. Przybyłowska, wiersze tłum. S. Bieniasz, Gliwice 2000, s. 50. Wśród badaczy nie ma zgody co do tej daty, opracowania podają je obie, por. http://www.literaturportal-bayern.de/autorenlexikon?task=lpbauthor.default\&pnd=118510754, dostęp: 1.05.2016 oraz Horst Bienek - Ein Schriftsteller in den Extremen des 20. Jahrhunderts, red. V. Nolte, R. Laube, Göttingen 2012, s. 277. 
częściowo wynika to z charakterystyki genologicznej utworów, częściowo jednak z wybranej przez pisarzy perspektywy retrospektywnej - ewentualne pozytywne emocje, które mogły towarzyszyć autorom na początku wycieczki, z pewnością przyćmiło doznane i opisane rozczarowanie Gliwicami.

W Podróży $w$ krainę dzieciństwa, która jest stylizowana na reportaż z podróży, rozczarowanie pojawia się stopniowo wraz z doznawanym zawodem, czy raczej narastającym uczuciem obcości. Bienek prowadzi narrację chronologicznie, rekonstruując odwiedziny w rodzinnych stronach etap po etapie, przeplatając opowieść wstawkami historycznymi i wspomnieniowymi. Specyfikę stylu oraz turystyki ojczyźnianej wyłożył pisarz w eseju Brzozy i wielkie piecie. Dzieciństwo na Górnym Ślasku, na pierwszej stronie czytamy:

Krainę dzieciństwa, jeśli długo była dla kogoś zamknięta, trudno jest po prostu odwiedzić w taki sposób, w jaki zwiedza się kraje dojrzewania. Tutaj jawią się wspomnienia, gwałtowne i zdumiewające, chwilami będące niczym uderzenia, pod którymi się wręcz kulę, pod obrazami rozpoznawanymi na nowo, wyłaniającymi się nie jeno z rzeczywistości, lecz i z podświadomości ${ }^{20}$.

Refleksja ta w pełni odnosi się do rytmu zwiedzania, jaki Bienek prezentuje w Podróży w krainę dzieciństwa. Nakładanie się rzeczywistości na obrazy z podświadomości łatwo rozpoznać w scenie konfrontacji z domem, w którym mieszkała rodzina pisarza. Postać nowego lokatora zlała się ze wspomnieniami o ojcu, dla Bienka było to niczym podróż w czasie:

Przez chwilę myślę: Mój Boże, jest tak, jak wtedy, nic się nie zmieniło. Ten człowiek, który wygląda jak mój ojciec, siedzi przy kuchennym stole i tnie wędzonkę w przezroczyste plasterki, i gdy mówi, wsuwa powoli nożem do ust jeden plasterek po drugim. $Z$ radia rozbrzmiewał wtedy metaliczny głos, ale nie słuchał. Obok siebie miał rozpostartą gazetę i od czasu do czasu do niej zaglądał (PWKD, s. 232).

Szczególną uwagę w cytowanym fragmencie zwraca różnica czasów, do opisu mężczyzny, który przypominał Bienkowi ojca, pisarz użył czasu teraźniejszego, w ogóle ten czas zarezerwowany został dla wszystkich opisów zwiedzania i spacerowania po mieście, natomiast nakładające się na rzeczywistość wspomnienie zostało wyrażone za pomocą czasu przeszłego. Tłumaczenie w tym fragmencie dość dobrze rekonstruuje strukturę oryginału. Pomimo zaznaczenia dwóch różnych porządków temporalnych obrazy zlewają się ze sobą, nie można ich rozłączyć. Przejście między teraźniejszością a przeszłością jest płynne i celowo zatarte, a nakładanie się na siebie planu wspomnieniowego z odwiedzinami było jedną z przyczyn zawodu pisarza, który uświadamiał sobie nieuchronny upływ czasu. Ostatecznie Bienek nie odnalazł ojczyzny

${ }^{20}$ H. Bienek, Brzozy..., dz. cyt., s. 5. 
w Gliwicach, choć bardzo tego pragnął. Konfrontacja geografii wyobrażonej z rzeczywistością zadziałała na niekorzyść tej pierwszej, w ostatnich akapitach Podróży czytamy bowiem: „Czy jest jakiś wynik mojej podróży? Górny Śląsk nie oznacza już dla mnie Heimat" (PWKD, s. 342).

Wolfgang Bittner swoją wycieczkę do Gliwic opisał w szkicu Ponowne spotkanie z Gleiwitz - Podróż do Polski, z przyjazdem go rodzinnego miasta pisarz czekał aż do zmian politycznych i otwarcia granic Rzeczypospolitej. Pierwsze akapity relacji są bardzo rzeczowe, Bittner podobnie jak Bienek rozpoczął swoją opowieść od przyjazdu, opisał krótko drogę, przeplatając wrażenia z informacjami historycznymi. Trudno się dopatrzyć stanu napięcia i radości, które towarzyszyły gliwickiemu uczniowi Bertolda Brechta. Autor Gliwice zwano kiedyś Gleiwitz analogicznie jednak jak twórca Pierwszej polki posłużył się czasem teraźniejszym do opisania podróży oraz zdania relacji ze zwiedzania, natomiast w czasie przeszłym wyraził wspomnienia (por. GZKG, s. 121). Bittner od początku nie krył uczucia obcości, którego doświadczył zaraz po przyjeździe:

Drzewa i stare domy otaczają wielopasmowe drogi. Mówię, że czuję się obco; przyjeżdżam do nieznanego mi miasta, niczego nie rozpoznaję. Te nieliczne wrażenia, które pozostały, rozmyte i nie pasują do tego miejsca. Wtedy, w 1945 roku, miałem cztery lata. Mieszkaliśmy na Barbarastraße, to pamiętam. Ale gdzie znajduje się ta ulica, która od dawna już nazywa się inaczej? (GZKG, s. 121).

W przypadku Bittnera trudno jednak mówić o wyobcowaniu i utracie ojczyzny w takim samym sensie, w jakim można opisywać doświadczenia Bienka czy Bukowskiego, bowiem autor Gliwice zwano kiedyś Gleiwitz, jak sam zaznacza, w momencie opuszczenia rodzinnego domu miał zaledwie cztery lata. Budzi wątpliwości, czy tak małe dziecko potrafiło zbudować silną więź z miastem. Wydaje się to mało prawdopodobne, związek z miastem pisarz raczej może zawdzięczać rodzicom, którzy prawdopodobnie niejednokrotnie opowiadali synowi o rodzinnym domu. We wrześniu 1990 roku, gdy Bittner wyjeżdżał, jego matka żyła i prosiła syna o zrobienie fotografii: „Moja matka przed wyjazdem polecała mi gorąco, abym wszystko fotografował. Chce wiedzieć, jak dziś wszystko wygląda; będzie bardzo zawiedziona” (GZKG, s. 122). Pisarz zatem nie tylko mógł się podzielić z nią wrażeniami z podróży, ale, zakładając jej potencjalny zawód, musiał także zdawać sobie sprawę z wyobrażeń, jakie żywiła kobieta. Nie będzie nadinterpretacją stwierdzenie, że Bittner wystąpił w roli depozytariusza wspomnień matki. Chociaż przeżył przymusową migrację i wraz z rodziną utracił ojczyznę, to ze względu na wiek bliżej mu do miana pokolenia „półtora”, które w kontekście Zagłady opisuje Marianne Hirsch ${ }^{21}$.

${ }_{21}$ Zob. A. Mach, Poetyka postpamięci i etyka świadkowania w badaniach Marianne Hirsch, „Humanistyka XXI wieku. Rocznik Doktorantów Wydziału Polonistyki Uniwersytetu Warszawskiego" 2010, $\mathrm{nr} 1$, s. 111. 
Bittner przyswaja przestrzeń wspólnoty, do której przynależy głównie dzięki zapośredniczeniu przez rodzinę, jego turystyka ojczyźniana wynika z emocjonalnego stosunku do Gleiwitz, ale jest to miasto nieistniejące, które powinno być raczej traktowane w kategoriach wyobraźni, stanowić element „privatopii”:

Wyobraźnia jako społeczna praktyka w procesie tematyzacji miejskich środowisk często wiąże się z pojęciem nostalgii. Następuje tu bowiem symboliczny zwrot ku temu, co wydaje się pewne, minione i wyidealizowane. (...) Pamięć służy tu bowiem swoistemu konsumowaniu przeszłości jako zbioru zrekonstruowanych wyobrażeń, które są manipulowane i przeobrażane. Tematyzacja wyobraźni prowadzi zatem do powstania tak zwanej wyobrażonej nostalgii za miastem, którego nie było ${ }^{22}$.

„Wyobrażona nostalgia”, o której pisze Małgorzata Nieszczerzewska, może być $\mathrm{z}$ powodzeniem odniesiona do Bittnera, podobnie jak manipulacje - szkic naszpikowany jest wzmiankami historycznymi oraz odwołaniami do pamięci rodziców pisarza (por. GZKG, s. 127), jego osobiste wspomnienia są mocno ograniczone ${ }^{23}$. Przede wszystkim jednak pisarz był świadomy, że doświadczenie przestrzeni Gleiwitz/Gliwic nie było dla niego, w przeciwieństwie do jego rodziców, doświadczeniem budującym tożsamość:

Chciałabym jednak poprzestać na tym wspomnieniu. Gleiwitz to dzisiaj Gliwice, około dwustutysięczne miasto w Polsce. Dla moich rodziców jest jednak inaczej. Dla nich Gleiwitz jest wciąż jeszcze domem i długi czas myśleli, że będą mogli tam wrócić (GZKG, s. 126).

Autor Gliwice zwano kiedyś Gleiwitz, podobnie jak Bienek, doznaje nagłych przebłysków pamięci, architektura pomaga pisarzowi w przypomnieniu wydarzeń z dzieciństwa, jest to jednak mechanizm nie tyle związany z turystyką ojczyźnianą, ile po prostu z charakterem pamięci.

Ciekawy na tle Bittnera i Bienka wydaje się przypadek Wolfganga Bukowskiego, który odwiedził miasto w 1989 roku, podobnie jak Bittner wykorzystując zmianę polityczną w Polsce oraz otwarcie granic. Niemniej jednak książka, która powstała po podróży w rodzinne strony, nie dokumentuje powrotu. Als wir jung in Gleiwitz waren... jest bowiem gliwicką biografią Bukowskiego, który snuje swoją opowieść od narodzin aż do momentu wyjazdu. Nie tylko charakter genologiczny wyróżnia książkę Wolfera, jak mówił o sobie

${ }^{22}$ M. Nieszczerzewska, Wyobraźnia [w:] Kulturowe studia miejskie..., dz. cyt., s. 207.

${ }^{23} \mathrm{Na}$ zapośredniczenie wspomnień Gliwic Bittnera przez pamięć rodzinną zwraca uwagę Sebastian Mrożek, zob. tenże, Gleiwitz heißt heute Gliwice. Horst Bieneks und Wolfgang Bittners Reiseerinnerungen an die oberschlesische Heimat im Spannungsfeld der Regionalität und Universalität [w:] Silesia in litteris servata. Paradigmen der Erinnerung in Texten schlesicher Autoren nach 1945, cz. 2, red. E. Białek, P. Zimniak, Drezno 2010, s. 274. 
autor, ale także sposób prowadzenia narracji - pisarz konsekwentnie używał trzeciej osoby liczy pojedynczej, opisując siebie niejako z poziomu meta. Ten zabieg uzmysławia dystans, który dzielił Bukowskiego od wydarzeń sprzed opuszczenia ojczyzny. Gliwicki okres Wolfer traktuje jako zamknięty rozdział - chronologicznie utwór kończy się w 1946 roku; teoretycznie pisarz mógtby kontynuować opowieść o swoim życiu, jednak doświadczenie przymusowej migracji stanowiło biograficzną cezurę, wydaje się też, że symbolizowało zerwanie zależności podmiotu od miejsca pierwotnie definiującego tożsamość Bukowskiego. Powrót, w sensie ewokowanym przez postulat Recht auf Heimat, musiał się wydawać pisarzowi niemożliwy, a sentymentalna podróż do rodzinnego miasta, choć nie była pozbawiona rysu emocjonalnego i musiała wzbudzać emocje Bukowskiego, w przeciwieństwie do wyjazdów Bienka i Bittnera, nie była próbą rekonstrukcji dzieciństwa ani odnalezienia utraconej ojczyzny. Zdaje się, że pisarz już w nastoletnich latach pogodził się z losem wygnańca, gdyż przymusową migrację opisuje w kategoriach przygody i szansy na normalne życie. Nie bez znaczenia jest dystans, którego nabrał Bukowski po latach, dzięki temu konieczność opuszczenia rodzinnego miasta pisarz opisuje bez resentymentów:

Wenn Wolfer abends ins Bett sank, hörte er von der Adolfstraße aus unten am Bahnhof die Züge rollen: Abenteuerlust packte ihn, Fernweh und ein neues Heimweh, und er ahnte: Gleiwitz ist Vergangenheit, eine neue Zukunft kommt auf uns zu; gesund werden nach einer (wie sich später herausstellte) Rippenfellentzündung, wieder normal reden und leben, lernen - und kein Angst mehr haben müssen (AWJ, s. 142).

Gdy wieczorem Wolfer zatopił się w łóżku, słyszał od ulicy Adolfa toczące się w dole dworca pociągi. Wyładowane były żądzą przygód, tęsknotą za wielkim światem i nieznaną tęsknotą za rodzinnymi stronami. Wolfer przeczuwał: Gliwice są przeszłością, zbliża się do nas nowa przyszłość, zdrowie (jak się później okazało) po zapaleniu opłucnej, znowu normalne rozmowy, życie, nauka - żadnego strachu więcej [tłum. - K.K.].

Szczególnie wyraźne na tle relacji Bienka, a przede wszystkim Bittnera, jest to, że Bukowski, mimo świadomości utraty ojczyzny, racjonalizuje opuszczenie Gliwic, poddając się dreszczykowi emocji, jaki dla nastolatka niosła ze sobą podróż w nieznane. Odjeżdżające pociągi nie były złowieszczym symbolem wygnania, lecz gwarantem przygody (niem. Abenteuerlust). Zadziwiające jest nastawienie Wolfera w kontekście doświadczeń, jakie dzieliła jego rodzina wraz z większością Niemców, którzy przeżyli wkroczenie Armii Czerwonej. Bukowski nie unika tematu wyzwalania miasta przez Sowietów, pisarz wspomina, jak został zabrany z domu na roboty (AWJ, s. 127), pamięta ewakuacyjny pochód więźniów KL Auschwitz, który zapadł w pamięć również 
Horstowi Bienkowi (AWJ, s. 114-116), Wolfer zdawał sobie sprawę z niepewności przyszłości: „Gliwice zostały opuszczone. Co Wolfer utracił, a co uzyska?" (AWJ, s. 168), a jednak pisarz wydaje się całkowicie pogodzony z losem. W przeciwieństwie do Bienka i rodziców Bittnera, którzy mogli wpajać synowi przywiązanie do Gliwic, Wolfer już w momencie wyjazdu nie miał złudzeń, że ewentualny powrót do miasta będzie niemożliwy. Być może właśnie dlatego śladów podróży sentymentalnej jest w Als wir jung... niewiele; drobna wzmianka o odnalezieniu przyjaciela oraz kilka zdjęć z prywatnej kolekcji autora - to wszystko.

Turystyka ojczyźniana koresponduje z kategoriami miejsca, przestrzeni oraz tożsamości. Literackie opracowanie jej wątków okazuje się zdradzać stosunek podmiotu do rodzinnych stron oraz traumę utraty ojczyzny. Podróże sentymentalne są rodzajem wtórnej konceptualizacji przestrzeni według schematów ustalonych w okresie jej zadomawiania. Nakładanie się wspomnień na odwiedzane miasta-miejsca daje się dobrze interpretować za pomocą kategorii palimpsestu, zgodnie z rozumieniem, jakie nadał temu terminowi Gérard Genette. Poszukiwanie śladów utraconej ojczyzny i utożsamianie się z nią bądź ponowne przeżywanie traumy utraty jest znaczące dla badania podmiotowości, dzięki turystyce ojczyźnianej uwidacznia się umiejętność redefinicji tożsamości, a także samo jej rozumienie reprezentowane przez odwiedzających rodzinne strony. Szczegółowa analiza fenomenu wymaga odrębnej pracy interpretacyjnej, jednak już samo wskazanie problemu pozwala dostrzec, że sposób podróżowania sentymentalnego oraz zawód doznawany na skutek konfrontacji z rodzinnymi stronami umożliwia podział turystów na dwie grupy: pierwsza reprezentuje substancjalny wzorzec tożsamości, druga nowoczesny, rozumiany w kategoriach narracyjności. Do pierwszej grupy zaliczyłabym Bittnera i Bienka, do drugiej Bukowskiego, który jako jedyny poddaje się zmianom i rozumie siebie pomimo zmieniającej się sytuacji egzystencjalnej. Doświadczenie przestrzeni, jak zostało już powiedziane, jest podstawowym dla definiowania się tożsamości, niemniej udomawianie i oswajanie, czynienie z niej miejsca napełnionego intymnym sensem i znaczeniem, może być zabiegiem wielokrotnym, wymaga jednak odejścia od prawa do ojczyzny, które lansowały ziomkostwa. Bukowski, jak wynika z lektury Als wir jung in Gleiwitz waren..., nawet jeśli przyszło mu to z trudnością, świadomie podjął się wyzwania budowania nowych relacji z miejscami, które stały się dla niego znaczące po wyjeździe z Gliwic. Natomiast Bienek definiował siebie w kategoriach śląskości, nieustannie tęskniąc za rodzinnymi stronami i dzieciństwem. Dopiero bolesne doświadczenie utraty i poczucie obcości w Gliwicach sprawiło, że pogodził się ze swoim losem i zakończył wieloletni okres pielgrzymstwa ${ }^{24}$. Bittner w najmniejszym stopniu spośród całej trójki definiował przestrzeń Gliwic jako

${ }^{24}$ Zob. K. Kuchowicz, Pielgrzymka do ojczyzny. Horsta Bienka powrót do Gliwic, „Zeszyty Naukowe Towarzystwa Doktorantów UJ Nauki Humanistyczne” 2015, nr 10, s. 25-38. 
„własną”, z jeden strony czuł się związany z miastem i zdecydował się na turystykę ojczyźnianą w pełnym tego słowa znaczeniu, z drugiej jednak podkreślał, że nie czuje więzi z Gliwicami. Autor Gliwice zwano kiedyś Gleiwitz określa siebie mianem wypędzonego, posługując się retoryką BdV, co pozwala się zastanawiać nad rzeczywistymi motywami podróży.

Warto zadać pytanie, dlaczego autorzy, poza Bukowskim, mieli problem z przepracowaniem utraty ojczyzny. Częściowej odpowiedzi można udzielić, powołując się na Recht auf Heimat, postulat ten bowiem stabilizował i utrwalat więź z utraconą ojczyzną, niejako utwierdzając osoby, które doświadczyły przymusowych migracji, że uparte trwanie przy tożsamości zdefiniowanej przed wojną, jest postawą słuszną. Dawanie nadziei na powrót w rodzinne strony i podtrzymywanie utożsamienia z opuszczonymi ojczyznami mocno ograniczało elastyczność podmiotu, którą wymagała asymilacja w dynamicznie zmieniającej się po drugiej wojnie światowej sytuacji geopolitycznej. Ocena, czy rzeczywiście Prawo do ojczyzny leży u podstawy negatywnych skutków turystyki ojczyźnianej, jest trudna, jeśli w ogóle możliwa, na pewno jednak żarliwa wiara w możliwość powrotu, którą wyrażał ten postulat, w konfrontacji z utraconą ojczyzną prowadziły do rozczarowania, gdyż wyobrażona ojczyzna bardzo rzadko odpowiadała realiom i nie przynosiła ostatecznego ukojenia.

\section{Bibliografia}

\section{Bibliografia podmiotowa}

Bienek H., Brzozy i wielkie piece. Dzieciństwo na Górnym Ślasku, tłum. W. Szewczyk, Gliwice 1991.

Bienek H., Podróż w krainę dziecinsstwa. Spotkanie ze Ślaskiem (wydanie dwujęzyczne), tłum. M. Podlasek-Ziegler, Gliwice 1993.

Bienek H., Stopniowe zamieranie krzyku, tłum. M. Podlasek-Ziegler, Gliwice 2000. Bittner W., Gleiwitz heißt heute Gliwice: eine deutsche-polnische Gesichte. Gliwice zwano kiedyś Gleiwitz: historia niemiecko-polska, Oberhausen, Wrocław 2003.

Bukowski W., Als wir jung in Gleiwitz waren..., Dülmen 2014.

\section{Bibliografia przedmiotowa}

Borne H., Doliński A., Organizacja turystyki, Warszawa 1998.

Charta der deutschen Heimatvertriebenen, http://www.bund-der-vertriebenen.de/ charta-der-deutschen-heimatvertriebenen.html, dostęp: 28.04.2016.

Dziuban Z., Doświadczenie [w:] Kulturowe studia miejskie. Wprowadzenie, red. E. Rewers, Warszawa 2014.

Halicka B., Polski Dziki Zachód. Przymusowe migracje i kulturowe oswajanie Nadodrza 1945-1948, tłum. A. Łuczak, Kraków 2015. 
Helbig L.F., Der ungeheure Verlust: Flucht und Vertreibung in der deutschsprachigen Belletristik der Nachkriegszeit. 3., um den aktuellen Forschungsstand und eine Register ergänzte Auflage, Wiesbaden 1996.

Horst Bienek - Ein Schriftsteller in den Extremen des 20. Jahrhunderts, red. V. Nolte, R. Laube, Göttingen 2012.

Horst Bienek, http://www.literaturportal-bayern.de/autorenlexikon?task=lpbauthor. default\&pnd=118510754, dostęp: 1.05.2016.

Kuchowicz K., Pielgrzymka do ojczyzny. Horsta Bienka powrót do Gliwic, „Zeszyty Naukowe Towarzystwa Doktorantów UJ Nauki Humanistyczne” 2015, nr 10.

Mach A., Poetyka postpamięci i etyka świadkowania w badaniach Marianne Hirsch, „Humanistyka XXI wieku. Rocznik Doktorantów Wydziału Polonistyki Uniwersytetu Warszawskiego” 2010, nr 1.

Mikołajczak M., Geografia wyobrażona regionu - wstęp do regionalnej komparatysty$k i$ [w:] Geografia wyobrażona regionu. Literackie figury przestrzeni, red. D. Kalinowski, M. Mikołajczak, A. Kuik-Kalinowska, Kraków 2014.

Mrożek S., Gleiwitz heißt heute Gliwice. Horst Bieneks und Wolfgang Bittners Reiseerinnerungen an die oberschlesische Heimat im Spannungsfeld der Regionalität und Universalität [w:] Silesia in litteris servata. Paradigmen der Erinnerung in Texten schlesicher Autoren nach 1945, cz. 2, red. E. Białek, P. Zimniak, Drezno 2010.

Nieszczerzewska M., Wyobraźnia [w:] Kulturowe studia miejskie. Wprowadzenie, red. E. Rewers, Warszawa 2014.

Święch J., Wygnanie. Prolegomena do tematu [w:] Narracja i tożsamość. Antropologiczne problemy literatury, t. 2, red. W. Bolecki, R. Nycz, Warszawa 2004.

Traba R., Żurek R. Vertreibung czy „przymusowe wysiedlenia”? Polsko-niemiecki spór o pojęcia, pamięć i sens uprawiania polityki wobec historii [w:] Przetom i wyzwanie. XX lat polsko-niemieckiego Traktatu o dobrym sąsiedztwie i przyjaznej wspótpracy 1991-2011, red. W.M. Góralski, Warszawa 2011.

Tuan Y.-F., Przestrzeń i miejsce, tłum. A. Morawińska, Warszawa 1987.

Welzer H., Moller S., Tschuggnall K., „Dziadek nie byt nazista”. Narodowy socjalizm i Holokaust w pamięci rodzinnej, tłum. P. Masłowski [w:] Pamięć zbiorowa i kulturowa. Wspótczesna perspektywa niemiecka, red. M. Saryusz-Wolska, Kraków 2009 (Horyzonty Nowoczesności).

Więckowski M., Turystyka na obszarach przygranicznych Polski, Warszawa 2010.

Wypędzeni ze Wschodu, red. H.-J. Bömelburg, R. Stößinger, R. Traba, tłum. J. Górny i in., Olsztyn 2001. 